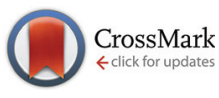

Cite this: Dalton Trans., 2016, 45 16157

Received 20th July 2016, Accepted 20th September 2016

DOI: $10.1039 / c 6 \mathrm{dt} 02881 \mathrm{k}$

www.rsc.org/dalton

\section{Oxygen reduction reaction catalyzed by nickel complexes based on thiophosphorylated calix[4]resorcinols and immobilized in the membrane electrode assembly of fuel cells $\uparrow$}

\author{
M. K. Kadirov, ${ }^{\star a, b}$ I. R. Knyazeva, ${ }^{a}$ I. R. Nizameev, ${ }^{a, c}$ R. A. Safiullin, ${ }^{b}$ V. I. Matveeva, ${ }^{a}$ \\ K. V. Kholin, ${ }^{a}{ }^{b}$ V. V. Khrizanforova, ${ }^{a}$ T. I. Ismaev, ${ }^{b}$ A. R. Burilov, ${ }^{a}$ Yu. H. Budnikova ${ }^{a}$ and \\ O. G. Sinyashin ${ }^{\mathrm{a}}$
}

The catalytic activity of the nickel complexes of thiophosphorylated calix[4]resorcinols for oxygen reduction in a polymer electrolyte membrane fuel cell (PEMFC) has been studied. The conformation of the macrocyclic ligand determines the morphology and catalytic properties of the resulting organometallic species.

Fuel cells are electrochemical devices that convert the chemical energy in fuels into the electrical energy directly, promising power generation with high efficiency and low environmental impact. However, the use of platinum-based PEMFC electrocatalysts remains a major issue for commercial introduction due to the scarcity of platinum and price pressures due to the increasing demand. ${ }^{1-3}$ Moreover, overpotentials as large as several hundred $\mathrm{mV}$, which result from poor oxygen-reduction reaction (ORR) kinetics on carbon-supported Pt catalysts, limit the rate of energy conversion in PEMFCs. ${ }^{2}$ The energy associated with this voltage loss is converted to heat, which has to be removed through a complex heat management. ${ }^{4}$ A crucial target is to improve the ORR catalyst at the cathodic end of hydrogen- and direct methanol-based fuel cells. ${ }^{5}$

The ORR is the foundation of biological aerobic energy generation. Efficient and rapid reduction of oxygen is carried out without the use or with the partial use of noble metals in nature by cytochrome $c$ oxidase enzymes to power the cellular proton pump during the final stage of respiration. ${ }^{4}$ Recently a

\footnotetext{
${ }^{a}$ A.E. Arbuzov Institute of Organic and Physical Chemistry, Kazan Scientific Center, Russian Academy of Sciences, 8, Akad. Arbuzov str., Kazan 420088, Russia. E-mail: kadirovmarsil@gmail.com

${ }^{b}$ Kazan National Research Technological University, 68, K. Marx str., Kazan 420015, Russia

${ }^{c}$ Kazan National Research Technical University, 10, K. Marx str., Kazan 420111, Russia

$\dagger$ Electronic supplementary information (ESI) available: AFM images of the nickel complexes of thiophosphorylated calix[4]resorcinol show the ligand in the cone or chair conformations, polarization and power density curves of the fuel cell with electrodes composed of the immobilized catalysts on carbon black and carbon black-supported Pt. See DOI: 10.1039/c6dt02881k
}

series of papers connected with the use of the biomimetic properties of organometallic complexes in the ORR for fuel cell (FC) membrane electrode assembly (MEA) have been published. ${ }^{6}$

Calix[4]arene derivatives have been used in catalytic reactions over the last four decades because they tend to be highly stable towards hydrolysis, a factor which makes them highly useful as catalysts. ${ }^{7}$ The chemistry of heteroatom-containing, in particular, phosphorus-containing, macrocyclic compounds including calixarenes has undergone rapid development; this is primarily related to the search for new and effective ligands for various applications in science and engineering. ${ }^{8,9}$ It was reported $^{8}$ that calix[4]resorcinols with four 2-thioxo-1,3,2-dioxaphosphorinane fragments included in aromatic substituents have been synthesized via a one-step condensation of resorcinol and its derivatives with a new para-thiophosphorylated benzaldehyde. It has been found that the diastereomeric ratio depends substantially on the reaction conditions, in particular the solvents and catalysts used. The macrocyclic products obtained are rett- (Fig. 1a) and/or rcc-isomers (Fig. 1b), which were isolated and the structures determined by NMR and single crystal X-ray diffraction studies. It has been found that the diastereomeric ratio depends substantially on the reaction conditions, in particular the solvents and catalysts used. The main feature of these compounds is that a metal can be loosely tethered at an entrance to a receptor cavity, thereby favouring interactions between properly oriented, coordinated substrates and the inner part of the hollow molecule. ${ }^{10}$ The presence of additional coordination centers in the macromolecules represented by four $\mathrm{P}=\mathrm{S}$ fragments with a hydrolytically stable tetracoordinate phosphorus atom enhances the complexation ability with various metal ions and extends the practical use of these compounds. We have designed membrane electrode assemblies with the $\mathrm{Ni}^{\mathrm{II}}$ complexes of thiophosphorylated calix[4]resorcinols as molecular catalysts separately for the anode and cathode, and for both the anode and cathode sides simultaneously, and then tested them in $\mathrm{H}_{2} / \mathrm{O}_{2}$ 
(a)



(b)
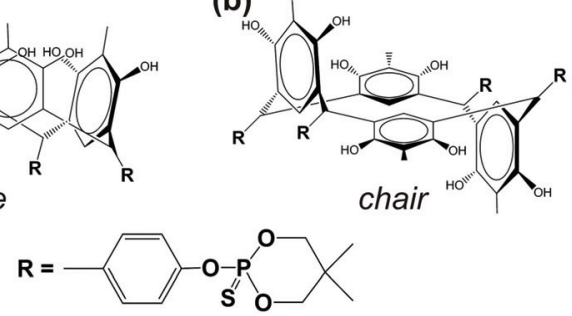

(c)

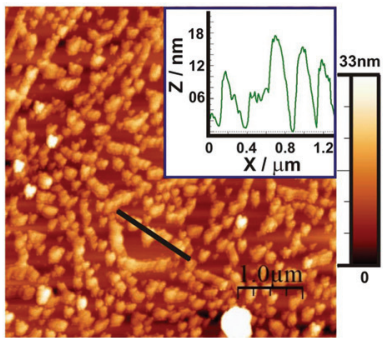

(d)

(e)
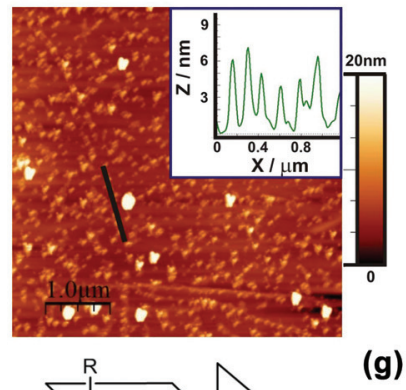

(g)
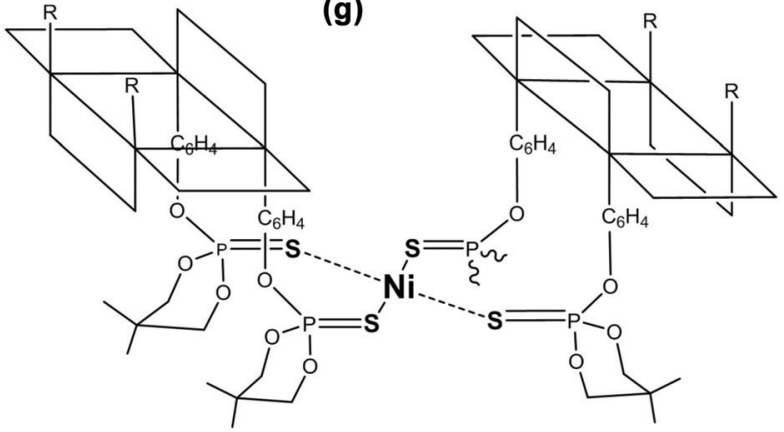

Fig. 1 Thiophosphorylated calix[4]resorcinols in (a) cone (1) and (b) chair (2) conformations. AFM images of 1 (c) and 2 (e) on HOPG, inset: cross section along a black line. Particles lateral size distribution corresponding to 1 (d) and 2 (f). (g) Schematic representation of nickel ion coordination of a flat-square $\mathrm{Ni}-\mathrm{S}_{4}$ coordination node formed in the $\mathrm{Ni}$ complex of calix[4]resorcinol in the chair conformation. An atomic force microscope MultiMode $\mathrm{V}$ has been used to reveal the morphology of the particles. The $250-350 \mathrm{kHz}$ cantilevers (Veeco, USA) with silicone tips (tip curvature radius is $10-12 \mathrm{~nm}$ ) have been used in all measurements. The microscopy images were obtained with $512 \times 512$ resolution. The scanning rate was $1 \mathrm{~Hz}$.

fuel cells. Below we discuss these original results together with the results of other independent methods.

Some of us have improved ${ }^{11}$ the method of Pt and Pd lattice production on the graphite surface. This method allows controlling the morphological characteristics of synthesized noble metal nanolattices. These characteristics directly depend on the morphological characteristics of the original hemi- and pre-cylindrical micellar templates. AFM proved to be very informative and is widely used to study the morphology of both micellar self-associated templates and metal clusters. MEAs with the noble metal nanolattices as the catalytic surface on both anode and cathode sides in a $\mathrm{H}_{2} / \mathrm{O}_{2}$ fuel cell have been designed and satisfactory diagnostic curves have been obtained.

In order to find out which particles form organometallic catalysts immobilized on a carbon substrate, we deposited them on an atomically smooth surface of pyrolytic graphite. Nickel complexes of thiophosphorylated calix[4]resorcinol 1 or 2 were prepared in situ by mixing salts of nickel $\mathrm{Ni}\left(\mathrm{BF}_{4}\right)_{2}$ with a ligand of cone or chair conformation, respectively, in the ratio of metal: ligand $=1: 1$ in DMF. The formation of particles (Fig. 1c) with an average lateral size of $220 \mathrm{~nm}$ (Fig. 1d) is typical of compound $\mathbf{1}$ with a cone conformation ligand. And particles (Fig. 1e) with a lateral size of $90 \mathrm{~nm}$ (Fig. 1f) are typical of compounds with two chair conformation ligands. The nickel ion in thiophosphorylated calix[4] resorcinol $\mathbf{1}$ is most probably coordinated near four sulfur atoms at the lower hydrophobic rim within one macromolecule. By means of these hydrophobic lower parts the complexes immobilize on a hydrophobic carbon substrate. The adjacent complexes immobilized in this way have been fastened on the upper hydrophilic surface of the complexes lying there with the hydrophilic upper rim down with a certain shift relative to the underlying complex. Complexes of the next layer also lie with some shifts relative to the neighbors on the underlying upper surface of the second layer with the hydrophobic rim down. Thus relatively large molecular aggregates of the polymer with vertical sizes of 10-18 $\mathrm{nm}$ are formed (Fig. 1c, inset). This corresponds to about 10-15 layers of the complex with the ligands in cone conformation. So a direct connection with the electrically conductive carbon substrate provides a relatively small amount of complex fragments and also the approach of oxygen molecules to the metal ion near the carbon substrate can be difficult. And perhaps this is one of the reasons why the nickel complex of the compound $\mathbf{1}$ does not function as a satisfactory oxygen reduction catalyst on the cathode side of the fuel cell, as shown in entry 1 of Table 1, demonstrating low currents and power densities with such a catalyst immobilized on the MEA. As can be seen in entry 3 of Table 1, the immobilization in MEA complex 2 with chair conformation of thiophosphorylated calix[4]resorcinols shows a power density of more than 5 times greater for the ORR in the fuel cell at the cathode. The chair conformation of the thiophosphorylated calix[4]resorcinols suggests that the metal ion can be coordinated in a complex by two sulfur atoms of the first thiophosphorylated calix[4]resorcinol and by two sulfur atoms of the second thiophosphorylated calix[4]resorcinol (Fig. 1h) forming flat-square coordinating node $\mathrm{Ni}-\mathrm{S}_{4}$, which is parallel and close to the carbon substrate surface. Metal : ligand ratio = $1: 1$ supposes the coordination of other metal ions by other substituents in the trans position of thiophosphorylated calix[4]resorcinol already involved in the coordination of the 
Table 1 Performance of the fuel cell with electrodes composed of immobilized catalyst 1 or $\mathbf{2}$ on carbon black and carbon blacksupported $\mathrm{Pt}^{\mathrm{a}}$

\begin{tabular}{llllll}
\hline & $\begin{array}{l}\text { Anode } \\
\text { Entry }\end{array}$ & $\begin{array}{l}\text { Cathode } \\
\text { catalyst }\end{array}$ & OCV $(\mathrm{V})$ & $\begin{array}{l}\text { Maximum } \\
\text { current density } \\
{\left[\mathrm{mA} \mathrm{cm}^{-2}\right]}\end{array}$ & $\begin{array}{l}\text { Maximum } \\
\text { power density } \\
{\left[\mathrm{mW} \mathrm{cm}{ }^{-2}\right]}\end{array}$ \\
\hline 1 & $\mathrm{Pt}$ & $\mathbf{1}$ & 0.470 & 12.8 & 0.726 \\
2 & $\mathbf{1}$ & $\mathrm{Pt}$ & - & - & - \\
3 & $\mathrm{Pt}$ & 2 & 0.538 & 48.4 & 3.924 \\
4 & $\mathbf{2}$ & $\mathrm{Pt}$ & 0.052 & 0.136 & 0.002 \\
5 & $\mathrm{Pt}$ & $\mathrm{Pt}$ & 1 & 1280 & 324
\end{tabular}

${ }^{a}$ Operating conditions: $T=80^{\circ} \mathrm{C}$, flow rate of water-saturated $\mathrm{H}_{2}$ gas = $20 \mathrm{~mL} \mathrm{m^{-1 }}$, flow rate of water-saturated $\mathrm{O}_{2}$ gas $=20 \mathrm{~mL} \mathrm{~min}{ }^{-1}$, humidity $100 \%$, active area of MEA $=1 \mathrm{~cm}^{2}$, proton-conducting polymer electrolyte: Nafion ${ }^{\circledR 212}$, carbon black: Cabot Corporation Vulcan XC-72, gas diffusion layer: Sigracet巴 25CC.

first Ni ion. The nickel complexes of compound 2 are more uniformly distributed over the surface of the carbon substrate forming smaller aggregates, whose height is $4-6 \mathrm{~nm}$ according to the inset in Fig. 1e. The latter implies a possible arrangement of these complexes in two or three layers, where the shortest distance between the nearest nickel ions is about $4 \mathrm{~nm}$. Such a large distance does not allow the capture of the oxygen molecule by two nickel ions of the immobilized complexes, which is a necessary condition for the four-electron reduction of oxygen with the formation of water molecules. ${ }^{12}$

Fig. 2a shows the diagnostic curves at $80{ }^{\circ} \mathrm{C}$ for the $\mathrm{H}_{2}-\mathrm{O}_{2}$ fuel cell with the cathode of the organometallic catalyst 2 and the Pt anode. The diagnostic characteristics of FC with the cathode of the organometallic catalyst 2 (entry 3 of the Table 1) are significantly better than the characteristics of FC with the cathode of the organometallic catalyst 1 (entry 1 of Table 1).

To find out other possible causes of such a significant difference in the catalytic abilities of the two isomeric forms of the organometallic catalyst the method of stationary electron spin resonance (ESR) was used. ESR proved to be a very productive method that can be applied in the direct registration of decomposition products in perfluorosulphonated membranes, ${ }^{13}$ investigation of the micelles of classical surfactants in bulk solutions, ${ }^{14}$ amphiphilic calix[4]arenes, ${ }^{15}$ and simultaneous studies of paramagnetic intermediates by electrochemistry and ESR. ${ }^{16}$ The ESR spin probe method ${ }^{17}$ and combination of the AFM and ESR methods allowed the study of the nature of surfactant surface aggregates more closely. ${ }^{18}$ The experiments on the electrochemical reduction of the Ni complexes of compounds $\mathbf{1}$ and $\mathbf{2}$ in $\mathrm{DMF}$ at a platinum working electrode (reference electrode: $\mathrm{Ag} / \mathrm{Ag}_{\mathrm{NO}}$ ) in a combined electrochemistry-ESR cell directly in the ESR X-band spectrometer cavity have been performed. Some differences in sample behavior have been revealed. Through reduction of the complex of 2 to a potential of $-2.5 \mathrm{~V}$ no signal appears. In the case of the complex of 1 at the potential of $-1.5 \mathrm{~V}$ a very intensive and wide ESR spectrum appears (Fig. 2b). Its magneticresonance parameters are: $g=2.19, \Delta H_{\mathrm{pp}}=680$ Gauss. A very (a)

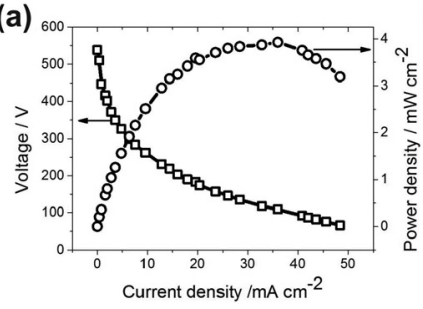

(c)

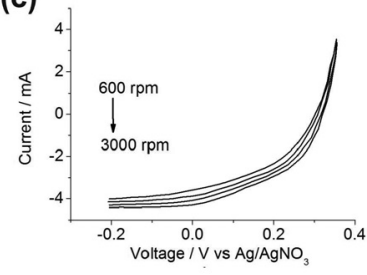

(b)

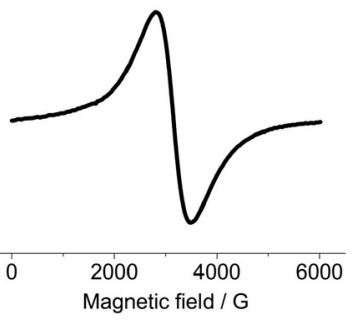

(d)

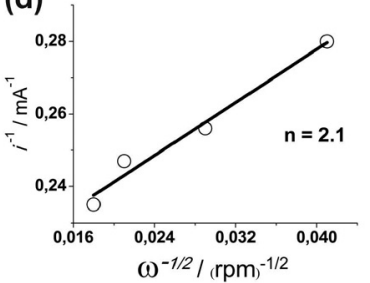

Fig. 2 (a) Polarization and power density curves at $80{ }^{\circ} \mathrm{C}$ for the $\mathrm{H}_{2}-\mathrm{O}_{2}$ fuel cell with the cathode of the organometallic catalyst 2 and the $\mathrm{Pt}$ anode (entry 3 in Table 1). The catalytic ink was prepared according to the following formulation: $0.5 \mathrm{mg}$ of organometallic catalyst and $5 \mathrm{mg}$ of Vulcan XC-72 were added to $375 \mathrm{~mL}$ of isopropyl alcohol (IPA). The ink was first sonicated for $15 \mathrm{~min}$ then $46 \mu \mathrm{L}$ of $5 \mathrm{wt} \%$ Nafion $\circledast$ solution (Aldrich) was added to the ink and sonicated again. The E-TEK $\left(\mathrm{Pt}_{20} / \mathrm{C}\right)$ catalytic ink was prepared according to the almost similar procedure: $20 \mathrm{mg}$ of E-TEK were added to $8.4 \mathrm{~mL}$ of IPA, then the ink was sonicated for $15 \mathrm{~min}$, and then $163 \mu \mathrm{L}$ of $5 \mathrm{wt} \%$ Nafion ${ }^{\circledR}$ solution were added to the ink and sonicated again. The obtained inks were deposited on the carbon paper gas diffusion layer (GDL) Sigracet ${ }^{\circledR}$ 25CC. MEA was obtained by hot-pressing GDLs on either side of a Nafion ${ }^{\circledR} 212$ membrane at $80^{\circ} \mathrm{C}$ with a load of about 200 lbs for 10 minutes. (b) The EPR spectrum of 1 at a potential of $-1.5 \mathrm{~V}$ in DMF vs. $\mathrm{Ag} / \mathrm{AgNO}_{3}$. (c) Currentpotential curves for the $\mathrm{O}_{2}$ reduction at rotating modified by the catalyst 2 glassy carbon disk electrode in $0.5 \mathrm{M} \mathrm{H}_{2} \mathrm{SO}_{4}$ saturated with $\mathrm{O}_{2}$. $\mathrm{Pt}$ counter electrode, $\mathrm{Ag} / \mathrm{AgNO}_{3}$ reference electrode, scan rate $=50 \mathrm{mV} \mathrm{s}{ }^{-1}$, disk area $=0.0314 \mathrm{~cm}^{2}$. To produce a modified adsorbed layer catalyst $20 \mu \mathrm{l}$ of the ink is applied to the horizontal surface of a glassy carbon disk and dried at room temperature for at least 10 minutes. (d) Koutecky-Levich plot of the inverse of the rotating disk current measured at $0 \mathrm{~V} v \mathrm{vs} . \mathrm{Ag} / \mathrm{AgNO}_{3}$ as a function of the square root of the inverse of the rotation rate. The fitted line yields 2.1 electrons. The parameters for the Koutecky-Levich plot including the diffusion constant of $\mathrm{O}_{2}$, concentration of $\mathrm{O}_{2}$ in $\mathrm{O}_{2}$-saturated aqueous solution, and kinetic viscosity of the solution were taken from ref. 12 .

large integrated intensity of the spectrum cannot be explained by the formation of paramagnetic particles in the solution. Indeed, the working electrode surface has changed its color to black. The same electrode continued to give a similar spectrum in the absence of the solution, indicating the formation of the paramagnetic film. It is known from the literature ${ }^{19}$ that $\mathrm{Ni}(0)$ gives the spectrum, which corresponds to all of the acquired parameters. So it can be concluded that the film contains $\mathrm{Ni}(0)$ formed on the electrode. Thus, in the case of the $\mathrm{Ni}$ complex of compound $\mathbf{1}$ at the FC operating potentials, at least part of the nickel ions are reduced to the metal dropping out of the catalytic process. Let's return to Table 1 , namely, to its entries 2 and 4, which show that complexes 1 and 2 immobilized in MEA hardly act as a hydrogen oxidation catalyst, having zero or near-zero current, voltage and power at the output of the corresponding FC, although some of us have 
recently found that the homogeneous nickel complexes of the thiophosphorylated calix[4]resorcinols showed high catalytic activity for hydrogen evolution from acidic solutions and stability in the electro-assisted catalysis at the surface of both glassy carbon and $\mathrm{Hg}$-pool electrodes. ${ }^{20}$ The possible reason for this contradiction, in our opinion, is the blocking of the active sites of the hydrogen oxidation in the molecular catalysts immobilized in MEA.

To study the ORR mechanism the voltammograms of the $\mathrm{O}_{2}$ reduction at the rotating glassy carbon disk electrode modified by the catalyst 2 in $0.5 \mathrm{M} \mathrm{H}_{2} \mathrm{SO}_{4}$ aqueous solution saturated with $\mathrm{O}_{2}$ have been acquired (Fig. 2c). A fitted KouteckyLevich line (Fig. 2d) of the inverse of the rotating disk current measured at $0 \mathrm{~V}$ versus $\mathrm{Ag} / \mathrm{AgNO}_{3}$ as a function of the square root of the inverse of the rotation rate yields 2.1 electrons.

Earlier we have already mentioned the work $^{12}$ which deals with a $\mathrm{Cu}^{\mathrm{I}}$ complex of 3-ethynyl-phenanthroline covalently immobilized onto an azide-modified glassy carbon surface. The rate of $\mathrm{O}_{2}$ reduction is second-order, suggesting that two $\mathrm{Cu}^{\mathrm{I}}$ species are necessary for the efficient 4-e reduction of $\mathrm{O}_{2}$. It has been proposed that a binding event occurs between two proximal $\mathrm{Cu}$ centers and a single $\mathrm{O}_{2}$ molecule to form a $\mathrm{Cu}_{2} \mathrm{O}_{2}$ intermediate species. A second $\mathrm{O}_{2}$-reduction pathway is due to site-isolated mononuclear $\mathrm{Cu}$ complexes, $\left\{\mathrm{Cu}^{\mathrm{I}}\right\}$, which reduce $\mathrm{O}_{2}$ by two electrons and two protons to $\mathrm{H}_{2} \mathrm{O}_{2}$ at more negative potentials. By analogy, it is logical to assume the presence of site-isolated mononuclear Ni complexes, $\left\{\mathrm{Ni}^{\mathrm{II}}\right\}$ (Fig. 1h), where the nickel ion captures an oxygen molecule. The modified glassy carbon or organometallic fuel cell cathode reduces it by two electrons and two protons to $\mathrm{H}_{2} \mathrm{O}_{2}$ according to Fig. 3 and eqn (1)-(3).

$$
\begin{gathered}
\left\{\mathrm{Ni}^{\mathrm{II}}\right\}+\mathrm{O}_{2} \rightarrow\left\{\mathrm{Ni}^{\mathrm{II}} \mathrm{O}_{2}\right\} \\
\left\{\mathrm{Ni}^{\mathrm{II}} \mathrm{O}_{2}\right\}+\mathrm{e}^{-} \rightarrow\left\{\mathrm{Ni}^{\mathrm{II}} \mathrm{O}_{2}{ }^{-}\right\} \\
\left\{\mathrm{Ni}^{\mathrm{II}} \mathrm{O}_{2}{ }^{-}\right\}+2 \mathrm{H}^{+}+\mathrm{e}^{-} \rightarrow\left\{\mathrm{Ni}^{\mathrm{II}}\right\}+\mathrm{H}_{2} \mathrm{O}_{2}
\end{gathered}
$$

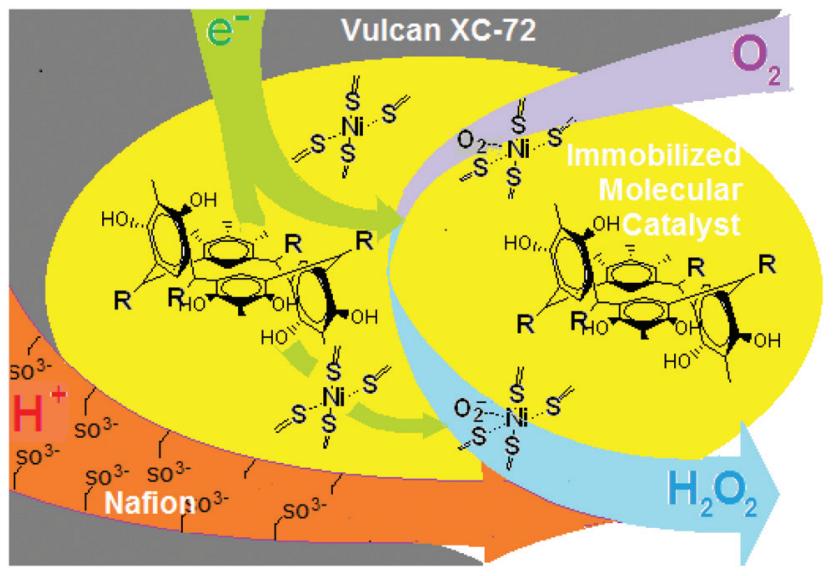

Fig. 3 Schematic representation of the reaction of the oxygen reduction by the immobilized molecular catalyst of the thiophosphorylated calix[4]resorcinol in the chair conformation.
Since the number of electrons transported in the ORR was found to be 2.1 , this reaction is $95 \%$ and goes through the two-electron mechanism with the formation of hydrogen peroxide.

So the catalyst for FC with the use of a perspective class of supramolecular compounds such as calix[4]resorcinols has been first built. The specific role in the catalysis of the stereoisomers of the nickel complexes of thiophosphorylated calix[4] resorcinols in both chair and cone configurations has been shown. The choice of other metal ions $\left(\mathrm{Co}^{\mathrm{II}}, \mathrm{Fe}^{\mathrm{II}}\right)$, variations of substituents at both the upper and lower rims of calix[4]resorcinols and types of conformational isomers could be a powerful tool in the development of effective molecular calixarene catalysts not only for ORR, but also for hydrogen or other fuels oxidation.

\section{Acknowledgements}

This work was financially supported by the Russian Science Foundation No. 14-23-00016.

\section{Notes and references}

1 G. Brumfiel, Nature, 2003, 422, 104; D. J. Berger, Science, 1999, 286, 49.

2 Q. He, T. Mugadza, X. Kang, X. Zhu, S. Chen, J. Kerr and T. Nyokong, J. Power Sources, 2012, 216, 67.

3 V. S. Murthi, R. C. Urian and S. Mukerjee, J. Phys. Chem. B, 2004, 108, 11011.

4 J. Y. Yang, R. M. Bullock, W. G. Dougherty, W. S. Kassel, B. Twamley, D. L. DuBois and M. R. DuBois, Dalton Trans., 2010, 39, 3001.

5 B. C. H. Steele and A. Heinzel, Nature, 2001, 414, 345.

6 T. Matsumoto, K. Kim and S. Ogo, Angew. Chem., Int. Ed., 2011, 50, 11202; X. Zhu, J. B. Kerr, Q. He, G. Hwang, Z. Martin, K. Clark, A. Z. Weber and N. Zhao, ECS Trans., 2012, 45, 143; T. Matsumoto, K. Kim, H. Nakai, T. Hibino and S. Ogo, ChemCatChem, 2013, 5, 1368; P. D. Tran, A. Morozan, S. Archambault, J. Heidkamp, P. Chenevier, H. Dau, M. Fontecave, A. Martinent, B. Jousselme and V. Artero, Chem. Sci., 2015, 6, 2050; M. K. Kadirov, T. I. Ismaev, R. A. Safiullin, I. R. Nizameev, I. D. Strelnik, E. I. Musina, Yu. H. Budnikova, A. A. Karasik and O. G. Sinyashin, Phosphorus, Sulfur Silicon, 2016, 191, DOI: 10.1080/10426507.2016.1212050.

7 C. Weiser, C. B. Dieleman and D. Matt, Coord. Chem. Rev., 1997, 165, 93.

8 I. R. Knyazeva, V. I. Sokolova, M. Gruner, W. D. Habicher, V. V. Syakaev, V. V. Khrizanforova, B. M. Gabidullin, A. T. Gubaidullin, Y. H. Budnikova, A. R. Burilov and M. A. Pudovik, Tetrahedron Lett., 2013, 54, 3538.

9 I. R. Knyazeva, V. I. Sokolova, M. Gruner, W. D. Habicher, Ju. K. Voronina, A. R. Burilov and M. A. Pudovik, J. Inclusion Phenom. Macrocyclic Chem., 2013, 76, 231; 
I. R. Knyazeva, V. I. Matveeva, V. V. Syakaev, B. M. Gabidullin, A. T. Gubaidullin, M. Gruner, W. D. Habicher, A. R. Burilov and M. A. Pudovik, Tetrahedron Lett., 2014, 55, 7209.

10 B. S. Creaven, D. F. Donlon and J. McGinley, Coord. Chem. Rev. , 2009, 253, 893.

11 M. Kadirov, I. Nizameev and L. Zakharova, J. Phys. Chem. C, 2012, 116, 11326; I. R. Nizameev, M. K. Kadirov, V. A. Semyonov, L. Ya. Zakharova, T. I. Ismaev, R. A. Safiullin, I. Kh. Rizvanov and V. M. Babaev, Dalton Trans., 2016, 45, 11035.

12 C. C. L. McCrory, A. Devadoss, X. Ottenwaelder, R. D. Lowe, T. D. P. Stack and C. E. D. Chidsey, J. Am. Chem. Soc., 2011, 133, 3696.

13 M. Kadirov, A. Bosnjakovic and S. Schlick, J. Phys. Chem. B, 2005, 109, 7664; M. Danilczuk, A. Bosnjakovic, M. Kadirov and S. Schlick, J. Power Sources, 2007, 172, 78; A. Bosnjakovic, M. Kadirov and S. Schlick, Res. Chem. Intermed., 2007, 33, 677.

14 T. Pashirova, E. Zhil'tsova, R. Kashapov, S. Lukashenko, A. Litvinov, M. Kadirov, L. Zakharova and A. Konovalov, Russ. Chem. Bull., 2011, 59, 1745.

15 L. Zakharova, Y. Kudryashova, N. Selivanova, M. Voronin, A. Ibragimova, S. Solovieva, A. Gubaidullin, A. Litvinov, I. Nizameev, M. Kadirov, et al., J. Membr. Sci., 2010, 364, 90.

16 M. Kadirov, Yu. Budnikova, T. Gryaznova, O. Sinyashin, M. Bubnov, A. Krashilina and V. Cherkasov, Russ. Chem. Bull., 2007, 56, 104; M. Kadirov, E. Tretyakov, Y. Budnikova, M. Valitov, K. Holin, T. Gryaznova, V. Ovcharenko and
O. Sinyashin, J. Electroanal. Chem., 2008, 624, 69; Y. Budnikova, T. Gryaznova, M. Kadirov, E. Tret'yakov, K. Kholin, V. Ovcharenko, R. Sagdeev and O. Sinyashin, Russ. J. Phys. Chem. A, 2009, 83, 1976; M. Kadirov, E. Tret'yakov, Y. Budnikova, K. Kholin, M. Valitov, V. Vavilova, V. Ovcharenko, R. Sagdeev and O. Sinyashin, Russ. J. Phys. Chem. A, 2009, 83, 2163; M. Kadirov, Y. Budnikova, K. Kholin, M. Valitov, S. Krasnov, T. Gryaznova and O. Sinyashin, Russ. Chem. Bull., 2010, 59, 466; J. Ciszewski, D. Mikhaylov, K. Holin, M. Kadirov, Y. Budnikova, O. Sinyashin and D. Vicic, Inorg. Chem., 2011, 50, 8630; R. Galimullina, M. Valitov, Y. Spiridonova, E. Musina, S. Krasnov, M. Kadirov, A. Karasik, Y. Budnikova and O. Sinyashin, Russ. J. Phys. Chem. A, 2011, 85, 2214; M. Kadirov, K. Kholin, E. Tselishcheva, V. Burilov and A. Mustafina, Russ. Chem. Bull., 2013, 62, 1327; K. Kholin, M. Valitov, V. Burilov, E. Tselischeva, S. Strekalova, A. Mustafina, Yu. Budnikova and M. Kadirov, Electrochim. Acta, 2015, 182, 212.

17 Y. Wang, D. Lu, H. Yan and R. Thomas, J. Phys. Chem. B, 1997, 101, 3953.

18 M. Kadirov, A. Litvinov, I. Nizameev and L. Zakharova, J. Phys. Chem. C, 2014, 118, 197854.

19 M. Stöcker, E. Tangstad, N. Aas and T. Myrstad, Catal. Lett., 2000, 69, 223.

20 V. V. Khrizanforova, I. R. Knyazeva, V. I. Matveeva Sokolova, I. R. Nizameev, T. V. Gryaznova, M. K. Kadirov, A. R. Burilov, O. G. Sinyashin and Y. H. Budnikova, Electrocatalysis, 2015, 6, 357. 